\title{
Mortality caused by accidental falls among the elderly: a time series analysis
}

\section{Abstract}

Introduction: The worldwide increase in the elderly population has highlighted the importance of accidental falls and their consequences. Objective: To perform time-trend analysis of the mortality rate from accidental falls in (1) the city of Florianópolis (2) the state of Santa Catarina and (3) Brazil. Method: A time-series study of data from the Sistema de Informação sobre Mortalidade ("the Mortality Information System") was performed. The variation in mortality caused by accidental falls was estimated using the joinpoint regression method, based on the International Disease Classification (ICD-10), chapter XX, codes W00 to W15 and W17 to W19, from 1997 to 2010. Results: It was observed that in the most recent periods (2005/2008; 2002/2008;2003/2008), there was a significant increase in mortality rates related to accidental falls in all three regions, and that these rates increased with advancing age. Conclusion: Strategies to prevent accidental falls among the elderly should be aimed, mainly, at those who are 80 and over, the age in which accidental falls result in higher death rates.

Key words: Accidental Falls; Elderly; Ecological Studies; Temporal Distribution; Mortality Rate; External Causes.

Complexo de Ensino Superior Meridional - IMED. Passo Fundo, RS, Brasil.

2 Universidade Federal de Santa Catarina, Centro de Ciências da Saúde, Curso de Fisioterapia. Araranguá, SC, Brasil.

3 Universidade Federal de Santa Catarina, Centro de Ciências da Saúde, Departamento de Saúde Pública - Programa de Pós-Graduação em Saúde Coletiva. Florianópolis, SC, Brasil. 


\section{INTRODUCTION}

In the last century, the growth rate of the population older than 60 in Brazil has been significantly faster than in wealthier societies. ${ }^{1}$ The country is growing progressively older at a faster and faster rate. Each year, 700,000 more elderly persons are incorporated into this segment of the age pyramid. ${ }^{2}$ One result of this dynamic is the increased demand among the elderly for health services, resulting in more frequent hospitalizations, a greater bed occupancy time than other age groups, and a greater number of deaths among this group. ${ }^{3}$

The global increase in the elderly population has highlighted the importance of falls and their consequences, which are a frequent cause of loss of function, early admission to long term care facilities, and increased morbidity and mortality among the elderly. ${ }^{4}$

A fall is defined as an unintentional, unexpected change in position, which places the individual at a lower level than before, for example, on the furniture or the floor. This event is not the result of sudden paralysis, seizure or an external force. ${ }^{5}$

For these reasons, falls constitute a public health problem as, in addition to representing the sixth leading cause of death among the elderly, ${ }^{6}$ they result in high morbidity and are among the leading causes of hospitalization among people aged 60 years or over. ${ }^{7}$ Deaths caused by external causes represented, on average, $22.5 \%$ of deaths among the elderly in the state capitals of Brazil, between the period 1996 and $2005 .^{8}$

In addition to causing fractures, falls have other consequences, such as a decreased quality of life, fear of walking and the loss of ability to perform tasks of daily life. About $5 \%$ of falls result in fractures and between $5 \%$ and $10 \%$ cause injuries which require medical care. ${ }^{9,10}$

The economic consequences of falls are also significant. Hospitalization or institutionalization results in increased costs for both health services and family members who must spend more on medication and care. ${ }^{11}$

In 2009 and 2010, a population-based study of 1,705 elderly persons in the city of Florianopolis, the capital of the state of Santa Catarina, found a prevalence of falls of $18.8 \%{ }^{12}$ Considering the percentage found, and the relevance of the theme, the present study was undertaken in order to evaluate the trends in mortality from falls in Florianopolis, the state of Santa Catarina and Brazil.

\section{METHOD}

An ecological type study was performed using the Mortality Information System (MIS) database of DATASUS/Ministério da Saúde (the Ministry of Health). ${ }^{13}$

Information for people 60 years of age or older, of both genders, living in Brazil, in the state of Santa Catarina and in the city of Florianopolis was gathered. The state of Santa Catarina is located in the south of Brazil and in 2010 had 6,248,426 inhabitants, of whom $10.5 \%$ were aged 60 or more. Florianopolis is the capital of Santa Catarina, with a population of 421,240 inhabitants, of whom $11.5 \%$ are elderly. ${ }^{14}$

The collection of mortality data was based on the MIS database. Deaths arising from falls, whether identified as such in primary or secondary diagnosis, considered in the 10th revision of the International Classification of Diseases (CID-10) ${ }^{15}$ codes W00 to W15 and W17 to W19 of Chapter XX - External causes of morbidity and mortality, were used.

Information on the number of elderly residents was obtained from the Instituto Brasileiro de Geografia e Estatística ("Brazilian Institute of Geography and Statistics”) (IBGE). Data for the years 1997 to 1999 and 2001 to 2006 was calculated from preliminary estimates of population totals for inter-census years and stratified by age and gender by MS/SGEP/DATASUS. For the years 2007-2009, the figures refer to estimates prepared 
as part of the UNFPA/IBGE Project (BRA/4/ P31A) - Population and Development, Population Coordination and Social Indicators, while for the years 2000 and 2010, the values used were from the Demographic Census ${ }^{16,17}$ of those years.

DATASUS data of both deaths and resident population was exported to Microsoft Excelß 2003, in which the annual mortality rates from falls, both crude and adjusted by age, were calculated to estimate trends in mortality.

Specific mortality rates from falls were calculated using the number of deaths from falls among the elderly in the area of interest in the given year, divided by the total population aged 60 or older in the same area and year, then multiplied by 100,000 (figure 1a).

The specific mortality rate from falls per 100,000 residents was calculated, as well as the specific mortality rate from falls for the age groups
60-69 years, 70-79 years and 80 years or older (figure 1b).

Next, the specific mortality rates from falls were standardized for age by the direct method, which uses the standard world population as a reference

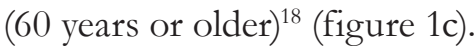

The age-adjusted rates calculated were used in the analysis of trends in mortality in the city of Florianopolis, the state of Santa Catarina and in Brazil, by estimating regression models. To smooth the time series, due to the oscillation of points caused by the small number of cases in certain strata, the moving average was calculated centered around five terms. In this process, the smoothed coefficient of year (i) $\left(Y_{a i}\right)$ corresponds to the arithmetic average of the coefficients of the two previous years, of the same year (i) and of the following two years (Figure 1d). Thus, the historical series presented represented the years 1999-2008, despite using information from 1997 to 2010.

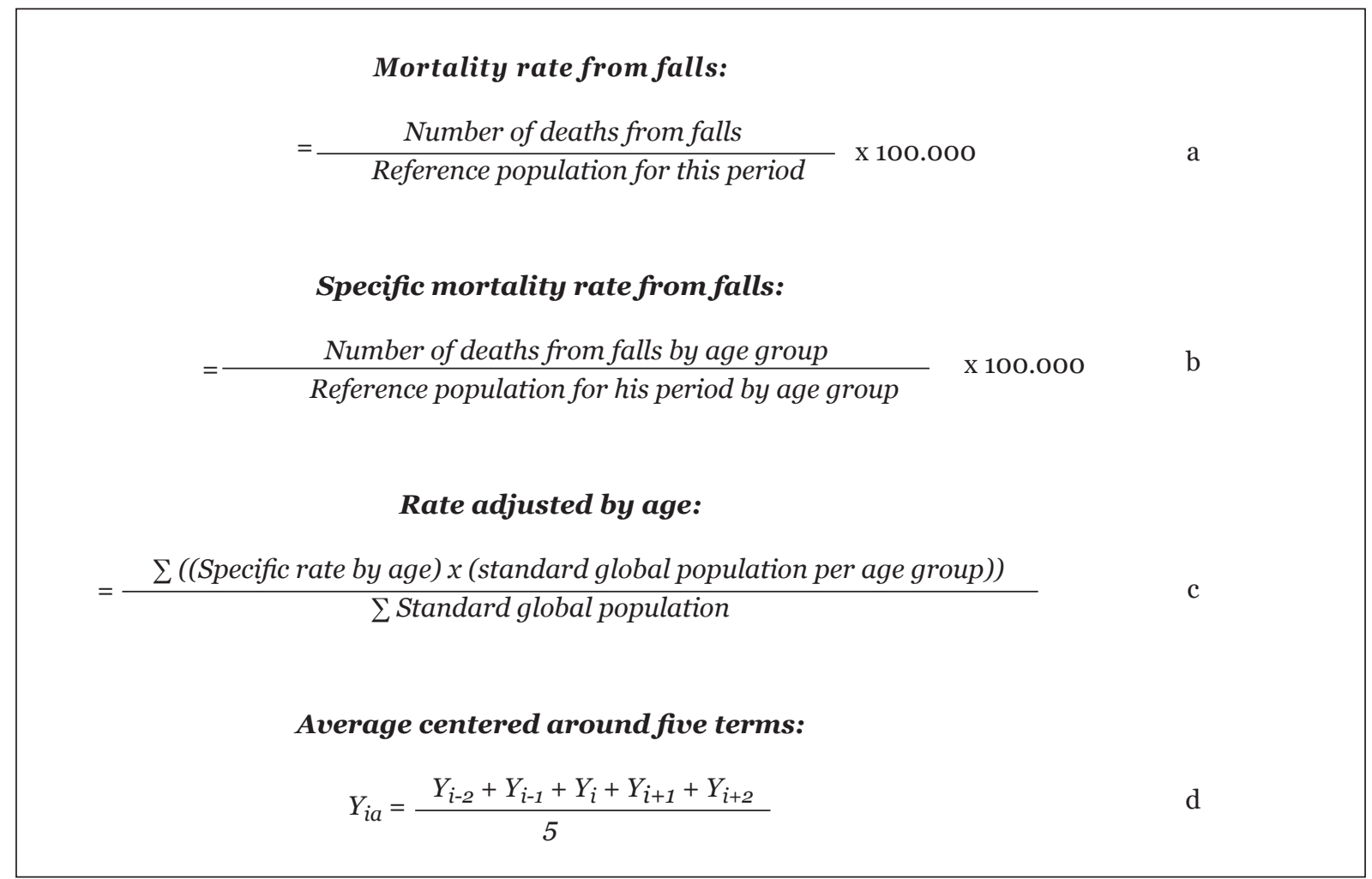

Figure 1. Formulas used for calculations. Florianopolis, SC, 2013. 
The Joinpoint program, version 3.5.4 (Statistical Research and Applications Branch, National Cancer Institute, United States), was used to calculate the annual change in mortality from 1999 to 2008 . The use of the joinpoint method allows the description of trends and identifies changes over time. The program performs segmented linear regression (jointpont regression) to estimate the annual percentage change and identify points where there is change in trends. ${ }^{19}$

From the estimated curve for each line segment the annual percentage change and its statistical significance is calculated, estimated by the least squares method for a generalized linear model. In this way, it was assumed that the rates followed a Poisson distribution, and that such variation is not constant over the period. ${ }^{19}$

\section{RESULTS}

During the study period (1997-2010), of $8,142,342$ deaths of people aged 60 and older in Brazil, 50,348 (0.61\%) were due to falls $(51.1 \%$ of such deaths involved men). A total of 916 (54.3\% of which involved men) of those falls occurred in the state of Santa Catarina, and 93 (50.5\% of which involved women) took place in Florianopolis (table 1). Of the 50,348 deaths, $50.6 \%$ occurred among the population aged 80 years or over. The crude and adjusted specific mortality rates from falls are shown in Table 1. These rates show variation between regions. In Brazil, the crude rate exceeded 30 deaths per 100,000 inhabitants, while in Santa Catarina, this rate fluctuated during the period, increasing in 2009 and 2010. There was also oscillation in Florianopolis, with a high of 62 deaths per 100,000 inhabitants in 2010. However, in analyzing the rates adjusted by age, it was found that in Brazil there was a progressive increase, while in Santa Catarina and Florianopolis there were variations over the period (Table 1).

Table 1. Specific Mortality Rates (MR) for falls among elderly persons* (per 100,000 residents) in Brazil, the state of Santa Catarina and the city of Florianopolis. Florianopolis, SC, 2013.

\begin{tabular}{cccccccccc}
\hline \multirow{3}{*}{ Year } & \multicolumn{3}{c}{ Brazil } & \multicolumn{4}{c}{ Santa Catarina } & \multicolumn{3}{c}{ Florianópolis } \\
\cline { 2 - 10 } & Deaths & $\begin{array}{c}\text { Gross } \\
\text { rate }\end{array}$ & $\begin{array}{c}\text { Adjusted } \\
\text { rate }\end{array}$ & Deaths & $\begin{array}{c}\text { Gross } \\
\text { rate }\end{array}$ & $\begin{array}{c}\text { Adjusted } \\
\text { rate }\end{array}$ & Deaths & $\begin{array}{c}\text { Gross } \\
\text { rate }\end{array}$ & $\begin{array}{c}\text { Adjusted } \\
\text { rate }\end{array}$ \\
\hline 1997 & 1.721 & 13.7 & 12.4 & 26 & 7.1 & 6.8 & 4 & 18.3 & 19.1 \\
1998 & 2.190 & 17.2 & 15.3 & 32 & 8.7 & 8.3 & 2 & 9.1 & 7.0 \\
1999 & 2.040 & 15.9 & 14.3 & 44 & 11.7 & 11.2 & 6 & 26.8 & 23.4 \\
2000 & 2.033 & 14.0 & 12.1 & 27 & 6.3 & 6.0 & 3 & 10.4 & 7.7 \\
2001 & 2.507 & 17.0 & 14.7 & 27 & 6.2 & 5.7 & 3 & 10.1 & 8.4 \\
2002 & 2.467 & 16.6 & 14.2 & 27 & 6.1 & 5.8 & 2 & 6.6 & 7.4 \\
2003 & 3.022 & 20.1 & 17.2 & 45 & 10.0 & 9.3 & - & - & - \\
2004 & 3.440 & 22.6 & 19.3 & 60 & 13.2 & 12.5 & 1 & 3.2 & 2.8 \\
2005 & 3.664 & 23.5 & 20.1 & 47 & 10.1 & 9.2 & 3 & 9.0 & 7.4 \\
2006 & 4.446 & 28.2 & 24.0 & 67 & 14.1 & 12.7 & 4 & 11.7 & 9.4 \\
2007 & 4.957 & 27.2 & 22.1 & 105 & 18.1 & 15.7 & 12 & 28.6 & 26.0 \\
2008 & 5.392 & 28.7 & 23.1 & 96 & 15.9 & 13.7 & 8 & 19.0 & 16.3 \\
2009 & 5.668 & 29.2 & 23.3 & 132 & 20.8 & 17.3 & 15 & 33.7 & 26.6 \\
2010 & 6.801 & 33.0 & 26.3 & 181 & 27.6 & 23.6 & 30 & 62.0 & 50.6 \\
\hline
\end{tabular}

*The coefficients of the years represent the mean of the two previous years, the year itself, and the two subsequent years. 
When analyzing the adjusted mortality rate per 100,000 residents for each age group, it appears that for all the areas surveyed, the death rate from falls increases with advancing age (Figure 2).

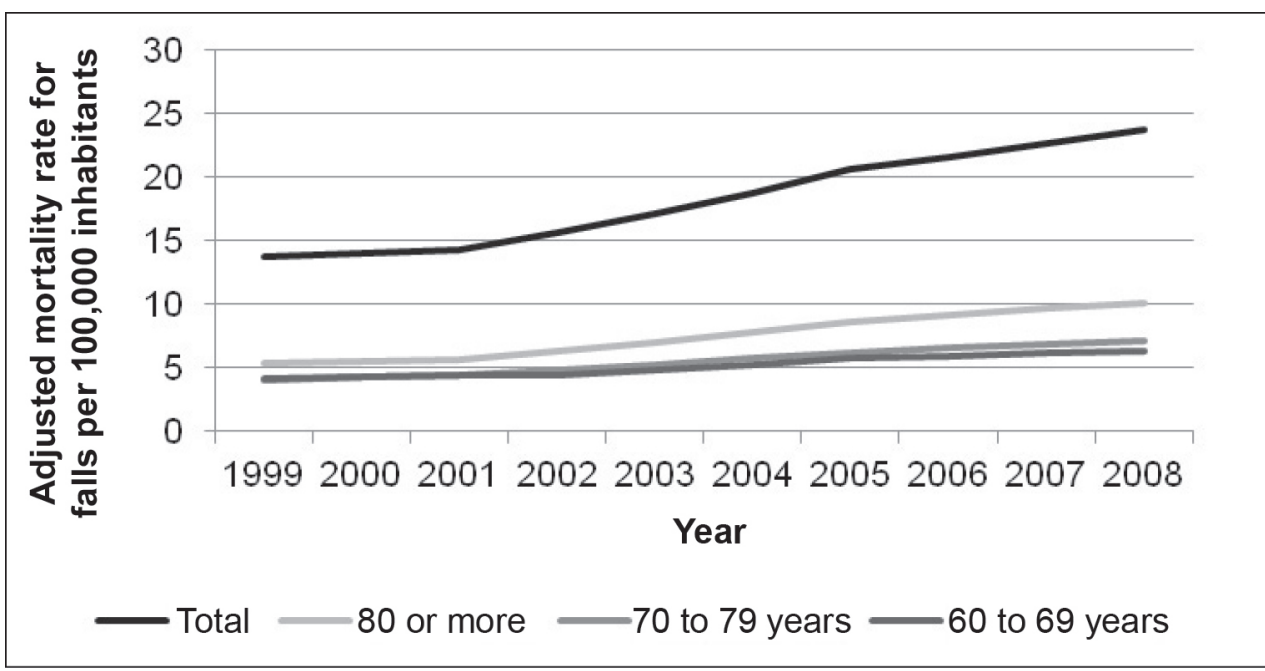

a. Brasil

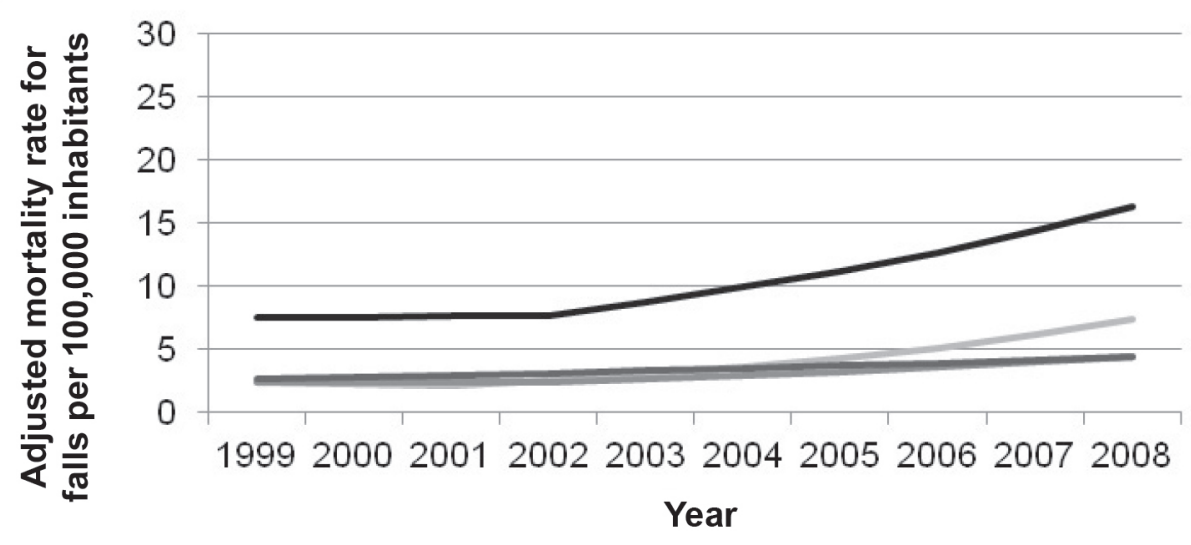

- Total -80 or more -70 to 79 years -60 to 69 years

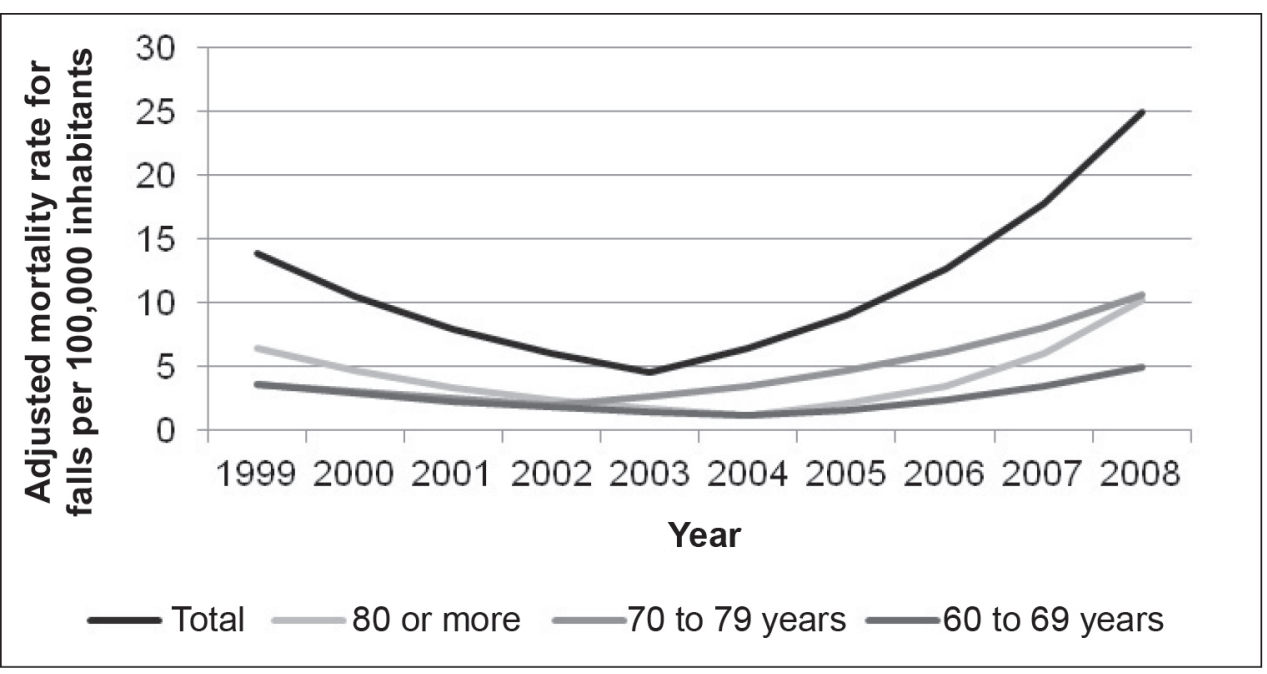

c. Florianópolis

Figure 2. Analysis of trends in mortality from falls by age group in Brazil 1 (a), Santa Catarina (b) and Florianopolis (c), 1999-2008. Florianópolis, SC, 2013. 
By analyzing the mean annual percentage change in mortality rate in the entire period between 1999 and 2008, there was a significant increase of 6.2\% for Brazil, 9.1\% for Santa Catarina and $6.7 \%$ for Florianopolis (Table 2).

Trends in the mortality rate from falls, without stratification by age group, oscillated between the periods. The trend for the city of Florianopolis, in which there were two periods of change, the first (1999-2003) with a significant reduction in mortality (24.2\%) and the second (2003-2008) with a significant increase in mortality (40.4\%), stands out. Although there were also two periods of change in Santa Catarina, this change was only significant in the period 2002-2008, with an increase of 13.3\% per year. For Brazil, there were three variations in trend, with a significant increase in 2011 (Table 2).

Table 2. Distribution of annual percentage variation, both overall and by age group, in Brazil, the state of Santa Catarina, and the city of Florianopolis, 1999-2008. Florianópolis, SC, 2013.

\begin{tabular}{|c|c|c|c|c|c|c|}
\hline & \multicolumn{2}{|c|}{ Brazil } & \multicolumn{2}{|c|}{ Santa Catarina } & \multicolumn{2}{|c|}{ Florianópolis } \\
\hline & Period & Variation & Period & Variation & Period & Variation \\
\hline \multicolumn{7}{|l|}{ Overall } \\
\hline & 1999-2008 & $6.2^{*}(5.6 ; 6.8)$ & 1999-2008 & $9.1 *(6.4 ; 11.9)$ & 1999-2008 & $6.7 *(1.3 ; 12.5)$ \\
\hline & 1999-2001 & $2.1(-1.7 ; 6.1)$ & 1999-2002 & $1.2(-7.3 ; 10.4)$ & 1999-2003 & $-24.2 *(-33 ;-14.3)$ \\
\hline & $2001-2005$ & $9.4 *(7.6 ; 11.4)$ & 2002-2008 & $13.3^{*}(10.6 ; 16)$ & 2003-2008 & $40.4^{*}(30.3 ; 51.2)$ \\
\hline & 2005-2008 & $4.8^{*}(3.2 ; 6.4)$ & & & & \\
\hline \multicolumn{7}{|l|}{$\begin{array}{l}80 \text { years } \\
\text { or more }\end{array}$} \\
\hline & 1999-2008 & $7.2 *(6.1 ; 8.4)$ & 1999-2008 & $13.6^{*}(9 ; 18.4)$ & 1999-2008 & $5.2(-7.0 ; 18.9)$ \\
\hline & 1999-2001 & $2.4(-4.9 ; 10.2)$ & 1999-2001 & $-5.1(-24.7 ; 19.5)$ & 1999-2004 & $-28.4^{*}(-42.6 ;-10.6)$ \\
\hline & $2001-2005$ & $11.1^{*}(7.5 ; 14.8)$ & $2001-2008$ & $19.6^{*}(16.9 ; 22.4)$ & 2004-2008 & $70.0^{*}(34.7 ; 114.5)$ \\
\hline & 2005-2008 & $5.5^{*}(2.6 ; 8.5)$ & & & & \\
\hline \multicolumn{7}{|l|}{$\begin{array}{c}70 \text { to } 79 \\
\text { years }\end{array}$} \\
\hline & 1999-2008 & $6.5^{*}(5.7 ; 7.2)$ & 1999-2008 & $7.0 *(3.8 ; 10.2)$ & 1999-2008 & $12.5^{*}(2.6 ; 23.4)$ \\
\hline & 1999-2001 & $3.8(-1 ; 8.9)$ & 1999-2002 & $-1.2(-10.7 ; 9.3)$ & 1999-2002 & $-17.7(-40.2 ; 13.4)$ \\
\hline & 2001-2005 & $9.1^{*}(6.8 ; 11.5)$ & 2002-2008 & $11.3^{*}(8.1 ; 14.6)$ & 2002-2008 & $31.5^{*}(20.6 ; 43.5)$ \\
\hline & $2005-2008$ & $4.8^{*}(2.8 ; 6.7)$ & & & & \\
\hline \multicolumn{7}{|l|}{$\begin{array}{c}60 \text { to } 69 \\
\text { years }\end{array}$} \\
\hline & 1999-2008 & $4.6^{*}(4.1 ; 5.2)$ & 1999-2008 & $5.7 *(4.2 ; 7.3)$ & 1999-2008 & $3.6(-2.9 ; 10.7)$ \\
\hline & 1999-2002 & $2.0 *(0.3 ; 3.7)$ & 1999-2008 & $5.7^{*}(4.2 ; 7.3)$ & 1999-2004 & $-20.8 *(-28.9 ;-11.8)$ \\
\hline & 2002-2005 & $8.7 *(5.5 ; 12)$ & & & 2004-2008 & $45.1 *(26.4 ; 66.6)$ \\
\hline & $2005-2008$ & $3.4^{*}(1.9 ; 4.8)$ & & & & \\
\hline
\end{tabular}

$*$ Value of $p<0.05$. 
When stratifying the study population by age group, it was found that, among elderly persons aged 80 or more, the annual percentage variation in the mortality rate was significant for Brazil and Santa Catarina for all the years analyzed, with increases of $7.2 \%$ and $13.6 \%$, respectively.

For this same age group, three variations in mortality were found in Brazil and Santa Catarina and two in the city of Florianopolis. The increase of $70 \%$ from the year 2004 onwards in Florianopolis is worthy of note. For the 70-79 year age group, the annual percentage change in the mortality rate was $6.5 \%$ in Brazil, $7.0 \%$ for the state of Santa Catarina and $12.5 \%$ for Florianopolis.

In Brazil, for the age group 70-79 years, three trends in mortality were found, reaching $9.1 \%$ in the period from 2001 to 2005 and decreasing to $4.8 \%$ in the years 2005-2008. At state level, two trends in mortality were observed, most notably the increase of $11.3 \%$ from 2002 to 2008 . At city level two periods (1999-2002; 2002-2008) were identiied, but without statistical significance.

Among those aged 60 to 69 years, the percentage of annual change in mortality rate was $4.6 \%$ at the national level and $5.7 \%$ within the state. Among the three periods with a significantly increasing trend in mortality in Brazil, the most significant was between the years 2001 and 2006, where growth reached $8.7 \%$. For the two periods evaluated for the city of Florianópolis, the years 2004 to 2008, in which the mortality trend reached $45.1 \%$ per annum, are worthy of note.

\section{DISCUSSION}

Overall, an increasing trend in mortality from falls among the elderly was identified, and it was found that this indicator increased as age advances, irrespective of the location investigated. This increase was more accelerated in the 80 years or older age group. This result is consistent with the knowledge that aging results in a worsening of disabilities, affects the functionality of the elderly and results in a greater number of falls., ${ }^{3,18}$ This increase, which grows with chronological age, is due to the cumulative effects of age-related disorders, diseases and an unsuitable environment. ${ }^{20,21}$

The annual growth in the mortality rate for falls observed in both Brazil and the state of Santa Catarina, shows that the outcome of death increased within the age group investigated, which makes the occurrence of falls of great significance.

Similar results were found in a study by Maciel et al. ${ }^{8}$ By analyzing mortality from external causes among elderly persons in state capitals during the period 1996 and 2005, it was found that on average, falls resulted in $22.5 \%$ of these deaths. In this study, it was found that while deaths from falls fluctuated in both absolute numbers and rates, the weight of these deaths in relation to mortality caused by external causes has grown each year, with an increase of almost $6.7 \%$ between 1996 and $2005 .^{8}$

The two trend periods identified for the city of Florianopolis also revealed fluctuation in the overall group, initially with a reduction in the mortality rate for falls (1999-2003), followed by an increase from the year 2003 onwards.

Other studies ${ }^{8,22}$ have also observed an oscillation in mortality by falls. Such findings may be explained by the fact that the data provided by the MIS can be influenced by the quality of the information recorded on the Declaration of Death (DD). Deaths whose underlying cause was recorded as "other external causes" or "nature of accidents not specified" or even "other transport accidents", would today be better defined.

For the total group in Brazil and Santa Catarina, there were three trend variations, with the period 2001-2005 standing out in both regions. This period saw the most significant increase in the percentage variation in mortality rates from falls, with a smaller increase occurring in the period 2005-2008.

When analyzing the overall group, it should be noted that the high rates found are influenced 
by the 80 and over age group, among which percentages were higher. This was confirmed by examining the annual percentage change in mortality rate in the 80 years or over age group, which presented significant values in all periods for Brazil and Santa Catarina. In Florianopolis the mortality trend reached a growth rate of $56.7 \%$ between 2003 and 2008 .

These results reveal a change in the mortality profile in the 80 years or older age groups, with the occurrence of more deadly events following falls. Another possible explanation is that more attention is now paid to health, meaning it is more likely that the elderly person who suffered the trauma that led to death will be attended by medical services, and thus improving the accuracy of the information on the DD.

According to the World Health Organization, ${ }^{23}$ the number of falls has grown as the number of elderly persons has increased in many countries of the world. Falls increase exponentially with the biological changes associated with aging, therefore, a greater number of people aged 80 years or over should trigger a substantial increase in falls and related injuries. ${ }^{23}$

For the 70-79 year age group, the trend of declining mortality did not present rectilinear behavior for any of the regions observed. However, the decrease observed for Brazil in the period between 2005 and 2008, which declined approximately $50 \%$, stands out.

Among elderly persons aged 60-69 years, the annual percentage change in the mortality rate showed lower values than for the other age groups. Of the mortality trend periods observed for all the regions, the city of Florianópolis, where the trend in mortality increased approximately $70 \%$ in the period 2005-2008, is worthy of note. Such a result may be related to the major differences between regions and states in relation to social and economic characteristics and quality of life, which strongly influence the quality ofvital records, ${ }^{24}$ which could in turn favor the city of Florianópolis, notable for its high sociodemographic conditions.

In addition to this increasing trend in mortality from falls, other studies have investigated the growing number of hospitalizations caused by injury. Mascarenhas et al., ${ }^{25}$ who, in a study of hospital admissions financed by the Sistema Único de Saúde ("the Unified Health System") in Brazil, found that the proportion of hospitalizations due to external causes showed a progressive increase $(7.7 \%$ in 2000 to $10.4 \%$ in 2010), while hospitalizations for cardiovascular disease remained constant, and hospitalizations for respiratory diseases decreased, in the same period. During the same period (2000 to 2010), the risk of hospitalization because of falls remained the highest, exceeding 15 hospitalizations per every 10,000 residents each year. ${ }^{25}$

The results of the present study highlight the importance of considering the diversity of the elderly population, reflected in the differences between age groups. There is heterogeneity in mortality patterns between the age groups of elderly persons, and therefore the impact of age group on the epidemiological profile of the population must be taken into account, considering their different priorities when planning health actions and strategies. ${ }^{26}$

A fall is a multifactorial event, comprising biological, behavioral, environmental and socioeconomic factors. ${ }^{27}$ Intervention projects that aim to reduce the occurrence of falls, therefore, should consider all these aspects. Data ${ }^{28}$ exists indicating that more wide-ranging projects involving environmental modification and physical activity have better results than those focusing on only one of the factors involved. One limitation of the present study is its use of secondary database information, which may have suffered underreporting. Increased efficiency in declaration of death certificates may have contributed to the increased rates found. 


\section{CONCLUSION}

Based on these results, there was an increasing trend in mortality from falls in the last period studied (2005/2008; 2002/2008; 2003/2008) in all the regions observed. Such growth, observed in Brazil and in the state of Santa Catarina, occurred mostly among elderly persons aged 80 years or older, the group for which more periods with a significant increase in mortality rates were identified, most notably for the state of Santa Catarina.

\section{REFERENCES}

1. Instituto Brasileiro de Geografia e Estatística. Indicadores sociais municipais: uma análise dos resultados do universo do censo demográfico 2010 [Internet]. Rio de Janeiro: IBGE; 2011 [acesso em jul. 2013]. (Estudos e Pesquisas); ( Informação Demográfica e Socioeconômica, n. 28). Disponível em: http://www.ibge.gov.br/home/estatistica/ populacao/censo2010/indicadores_sociais_ municipais/indicadores_sociais_municipais.pdf

2. Veras RP. Estratégias para o enfrentamento das doenças crônicas: um modelo em que todos ganham. Rev Bras Geriatr Gerontol 2011;14(4):779-86.

3. Veras RP. Envelhecimento populacional contemporâneo: demandas, desafios e inovações. Rev Saúde Pública 2009;43(3):548-54.

4. Gama ZAS, Gómez-Conesa A. Factores de riesgo de caídas en ancianos: revisión sistemática. Rev Saúde Pública 2008;42(5):946-56.

5. Andres RO, Coppard LC, Gibson MJS, Kennedy TE, Kellogg International Work Group on the Prevention of Falls by the Elderly. The prevention of falls in later life. Dan Med J 1987;34(4):1-24.

6. Pereira C, Vogelaere P, Baptista F. Role of physical activity in the prevention of falls and their consequences in the elderly. Eur Rev Aging Phys Act 2008;5(1):51-8.

7. Ribeiro AP, Souza ER, Atie S, Souza AC, Schilithz AO. A influência das quedas na qualidade de vida de idosos. Ciênc Saúde Coletiva 2008;13(4):1265-73.
While institutions such as the World Health Organization and the Brazilian Ministry of Health are working more effectively at creating policies to prevent falls among the elderly, creating guides on how to prevent this danger, the results of the present study indicate that the number of deaths due to falls increases with advancing age, and therefore, actions aimed at preventing falls should especially focus on, among the elderly population, the 80 years and over age group, in which falls more often lead to death.

8. Maciel S, Maciel WV, Teotônio PM, Barbosa GG, Lima VGC, De Farias OT, et al. Perfil epidemiológico das quedas em idosos residentes em capitais brasileiras utilizando o Sistema de Informações sobre Mortalidade. Rev AMRIGS 2010;54(1):25-31.

9. Fabrício SCC, Rodrigues RAP, Costa Junior ML. Causas e conseqüências de quedas de idosos atendidos em hospital público. Rev Saúde Pública 2004;38(1):93-9.

10. Antes DL, D'Orsi E, Benedetti TRB. Circunstâncias e consequências das quedas em idosos de Florianópolis. Epi Floripa Idoso 2009. Rev Bras Epidemiol 2013;16(2):469-81.

11. Antes DL, Schneider IJC, Benedetti TRB, D'Orsi E. Medo de queda recorrente e fatores associados em idosos de Florianópolis, Santa Catarina, Brasil. Cad Saúde Pública 2013;29(4):758-68.

12. Instituto Brasileiro de Geografia e Estatística. Indicadores Sociodemográficos e de Saúde no Brasil [Internet]. Rio de Janeiro: IBGE; 2009 [acesso em 02 set. 2013]. (Estudos e Pesquisas informação demográfica e socioeconômica, n. 25.). Disponível em: http://www.ibge.gov.br/home/estatistica/ populacao/indic_sociosaude/2009/indicsaude.pdf

13. Departamento de Informática do SUS - Datasus [Internet]. Brasília, DF: Ministério da Saúde. 2008- . Sistema de Informações sobre Mortalidade - SIM. Óbitos p/ residência por grupo CID-10. [acesso em 5 mai. 2014]; [aproximadamente 2 telas]. Disponível em: http://tabnet.datasus.gov.br/cgi/tabcgi.exe?sim/cnv/ obt10sc.def 
14. Instituto Brasileiro de Geografia e Estatística [Internet]. Rio de Janeiro: IBGE; [1995 - ]. Cidades@; 2014; [acesso em maio de 2104]; [aproximadamente 2 telas]. Disponível em: http://cod.ibge.gov.br/2K2R.

15. Instituto Brasileiro de Geografia e Estatística. Síntese de Indicadores Sociais: uma análise das condições de vida da população brasileira [Internet]. Rio de Janeiro: IBGE; 2012 [acesso em ago. 2013]. Disponível em: ftp://ftp.ibge.gov.br/Indicadores_Sociais/Sintese_ de_Indicadores_Sociais_2012/SIS_2012.pdf

16. Instituto Brasileiro de Geografia e Estatística. Sinopse do Censo Demográfico de 2010 [Internet]. Rio de janeiro: IBGE; 2011 [acesso em ago. 2013]. Disponível em: http://www.ibge.gov.br/home/ estatistica/populacao/censo2010/sinopse.pdf

17. Instituto Brasileiro de Geografia e Estatística [Internet]. Rio de Janeiro: IBGE; [1995- ]. Censo 2000; [acesso em jul. 2013]; [aproximadamente 2 telas]. Disponível em: http://www.ibge.gov.br/home/ estatistica/populacao/default_censo_2000.shtm

18. Doll R, Payne P, Waterhouse J. Cancer incidence in five continents: a technical report. Berlin: SpringerVerlag; 1966.

19. Kim H, Fay M, Feuer E, Midthune D. Permutation tests for joinpoint regression with applications to cancer rates. Stat Med 2000;19(3):335-51.

20. Brasil. Ministério da Saúde. Envelhecimento e Saúde da Pessoa Idosa. Brasília, DF: Ministério da Saúde; 2007. (Série A. Nomas e Manuais Técnicos); (Cadernos de Atenção Básica, n. 19).

21. Silva VL, Albuquerque MFPM, Cesse EAP, Luna CF. Perfil de mortalidade do idoso: análise da evolução temporal em uma capital do Nordeste brasileiro de 1996 a 2007. Rev Bras Geriatr Gerontol 2012;15(3):433-41.

22. Mathias TAF, Jorge MHPM, Andrade OG. Morbidity and mortality due to external causes among elders in the south of Brazil. Rev Latinoam Enferm 2006;14(1):17-24.

23. World Health Organization. World Health Organization global report on falls prevention in older age. Geneva: WHO; 2007 [acesso em jun. 2013]; Disponível em: http://www.who.int/ageing/ publications/Falls_prevention7March.pdf

24. Paes NA. Avaliação da cobertura dos registros de óbitos dos estados brasileiros em 2000. Rev Saúde Pública 2005;39(6):882-90.

25. Mascarenhas MDM, Monteiro RA, Sá N, Gonzaga L, Neves A, Silva M, et al. Epidemiologia das causas externas no Brasil: morbidade por acidentes e violências. Brasília, DF: Ministério da Saúde; 2010 [acesso em mai. 2013]; Disponível em: http://portal. saude.gov.br/portal/arquivos/pdf/cap_10_saude_ brasil_2010.pdf

26. Oliveira TC, Medeiros WR, Lima KC. Diferenciais de mortalidade por causas nas faixas etárias limítrofes de idosos. Rev Bras Geriatr Gerontol 2015;18(1):85-94.

27. Stevens JA, Baldwin GT, Ballesteros MF, Noonan RK, Sleet DA. An older adult falls research agenda from a public health perspective. Clin Geriatr Med 2010;26(4):767-79.

28. Letts L, Moreland J, Richardson J, Coman L, Edwards M, Ginis KM, et al. The physical environment as a fall risk factor in older adults: systematic review and metaanalysis of cross-sectional and cohort studies. Aust Occup Ther J 2010;57(1):51-64 . 